Kosztopulosz Andreász - Kuruczleki Éva (szerk.) (2020): Társadalmi és gazdasági folyamatok elemzésének kérdései a XXI. században. Szegedi Tudományegyetem Gazdaságtudományi Kar, Szeged, https://doi.org/10.14232/tgfek21sz.3

\title{
A lengyel export technológiai igényessége - változások a
}

\section{4-2017 közötti időszakban*}

\author{
Elżbieta Czarny - Paweł Folfas - Edward Molendowski
}

\begin{abstract}
A tanulmány célja a lengyel áruexport 2004 és 2017 közötti változása elemzése eredményeinek a bemutatása, különös figyelemmel technológiai igényességére Az elemzés tárgya a lengyel kivitel nagyságának, valamint földrajzi- és áruszerkezetének változása. Ez a tanulmány megmutatja, mennyire sikerül Lengyelországnak felzárkóznia az Európai Unió vezetö gazdaságaihoz, és mennyire messze van tölük gazdaságilag. Az elemzést azzal az évvel kezdjük, amelyikbenr Lengyelország csatlakozott az Európai Unióhoz, és azzal az évvel fejezzük be, amelyröl statisztikai adatok állnak rendelkezésre. A tanulmány korlátozott terjedelme miatt az áruk exportjára összpontositunk, nem véve figyelembe a szolgáltatások exportját. Lemondunk az import elemzéséröl is, csak arra korlátozzuk a vizsgálatát, hogyan változott a kereskedelmi mérleg egyenlege, amely - közvetett módon - megmutatja a lengyel export helyzetét.
\end{abstract}

Kulcsszavak: Lengyelország gazdasága, export, áruszerkezet, földrajzi szerkezet, technológiai igényesség

\section{Bevezetés}

A rendszer transzformációja és az Európai Unión belüli tagság, valamint - korábban - a csatlakozás előtti megállapodások jelentősen megváltoztatták a lengyel kivitel nagyságát és földrajzi szerkezetét ${ }^{1}$. Lengyelország szabad hozzáférést kapott az EU piacához, és alkalmazkodott az uniós normákhoz és szabványokhoz. A csatlakozás bejelentése, majd maga a csatlakozás, hozzájárult a külföldi befektetések Lengyelországba történő áramlásához. Ennek eredményeként a gazdaság modernizálódott, és nőtt a lengyel termékek versenyképessége. Amikor 2008 őszén kitört a világgazdasági válság, amely egy évvel később a nemzetközi kereskedelem

\footnotetext{
* A projektet a Narodowe Centrum Nauki (Nemzeti Tudományos Központ) finanszírozta (projekt regisztrációs száma: 2015/17/B/HS4/02075).

11991 decemberében Lengyelország társulási megállapodást kötött az Európai Gazdasági Közösséggel (EGK) (Európa Megállapodás). A megállapodás kereskedelmi része (Átmeneti Megállapodás) 1992 márciusától volt hatályban. Ennek értelmében Lengyelország és az EGK-országok tíz éven belül szándékoztak az ipari termékek szabadkereskedelmi övezetét létrehozni. A lengyel áruk nagy része már korábban, 1996-ban, bejutott az unió piacára. Az EU azonban akkoriban fenntartotta a Lengyelországból származó behozatal korlátozásait úgynevezett „érzékeny termékek”, elsősorban munka- és nyersanyagigényes (vas és acél, vegyi, textil és élelmiszeripari termékek, lábbelik) termékek esetén, amelyek az EU-ba irányuló lengyel exportnak majdnem a felét tették ki. Lengyelország ellenben megszüntette a vámot az EU-ból származó behozatala értékének csaknem 30\%-ára, megtartva az importkorlátozásokat, többek között gépkocsik valamint mezőgazdasági és élelmiszeripari termékek importjában.
} 
példátlan összeomlásához vezetett (Czarny-Śledziewska 2012, 134. o.), a lengyel gazdaság már elég erős volt ahhoz, hogy átvészelje ezt a sokkot. Ennek ellenére a válság hatással volt a lengyel exportra. Tíz év telt el a válság óta, amelynek során várható volt, hogy Lengyelország gazdaságilag közelebb kerül a legfejlettebb EUországokhoz (azaz az EU-15-hez). Az ilyen konvergencia megnyilvánulása lenne a technológiailag fejlett termékek kivitelének fejlődése és a nyersanyag- és munkaigényes termékek velük való helyettesítése. Ellenőrizzük, hogy történt-e ilyen áttörés. Érdekel bennünket az is, hogy a lengyel termékek hogyan teljesítenek az unión kivüli piacokon. A tanulmányban elválasztjuk az Európai Unióba irányuló lengyel exportot, ahol az Uniót 27 ország (28 ország minusz Lengyelország) összességének tekinjük, azaz jelenlegi formájában, valamint a világ más országaiba (a világ többi része, EU-n kívüli országok) irányuló exportot. Ezt a megosztást alkalmazzuk, bár tudjuk, hogy az EU-tagság radikálisan megváltoztatta a lengyel áruk versenyképességét valamennyi piacon. Erröl többek között az EU normáinak és szabványainak megfelelő javuló minőségü termékek döntöttek, amelyeket a világ vezető gyártói állitanak elö, akik Lengyelországban müködtetik gyáraikat.

E két típusú kereskedelmi partner tanulmányozása lehetővé teszi a lengyel termékek értékesítési lehetőségeinek felmérését azon a piacon, amelyhez Lengyelország szabadon hozzáférhet (EU), és a korlátozott hozzáférésü piacokon (a világ többi része). Az EU-n kívüli országokba irányuló export esetében a korlátozások a kereskedelmi partnerek protekcionista politikájából fakadnak. Az EU-ba irányuló kivitel intenzitása mutatja Lengyelország és a többi tagállam közötti integráció szintjét, míg az EU-n kívüli országokba irányuló kivitel az EU-tagságtól független gazdasági kapcsolatokról tájékoztat. A külső export bizonyítja a lengyel áruk versenyképességét akadályok által korlátozott kereskedelemben, mivel az Unión kívüli partnerek - még ha kapcsolatban is állnak az Unióval kereskedelmi preferenciákat tartalmazó megállapodásokkal - gyakran védik saját piacukat a külföldi áruk beáramlása ellen, például nem tarifális korlátozásokkal, amelyekre a kereskedelem liberalizációja nem terjed ki.

A tanulmány további részének a szerkezete a következő. Az irodalom áttekintésével kezdjük és a kutatási hézag megmutatásával. Ezután rátérünk az export átfogó elemzésére, melynek keretében megvizsgáljuk (1) a Lengyelországból származó export volumenének változásait a 2004-2017-es időszakban (2) a kereskedelmi mérleg egyenlegét, amelyek megmutatja, hogy az export elegendő-e az importigények fedezéséhez valamint (3) a lengyel kivitel földrajzi irányainak változását, felosztva a kereskedelmi partnereket az Európai Unióra és a világ többi részére, és azt is megvizsgáljuk, hogy mely országok voltak a lengyel áruk fỏ átvevői 2004-ben és 2017-ben. A következő részben elemezzük a lengyel export anyagszerkezetének változásait a vizsgált időszakban a technológiai igényesség szempontjából. Ez lehetővé teszi annak megállapitását, mennyire használta ki Lengyelország a csatlakozás előtti alkalmazkodásnak és az Európai Unióban való tagságnak köszönhetően kapott lehetőségeket, következésképpen a legfejlettebb EUtagokhoz való felzárkózásnak köszönhető lehetőségeket. 


\section{Irodalmi áttekintés}

Az export technológiai igényességének vizsgálatához a legmegfelelőbb klasszifikáció a Lall osztályozás (2000), amely bár elég régen született, csak néhány évvel ezelött terjedt el széles körben, annak köszönhetően, hogy bekerült az UNCTAD adatbázisába. Ez lehetővé teszi a termékek csoportokba való besorolását összetételüktől és technológiai igényességüktől függően.

Lall 11 terméktípust különböztet meg. Ezek a következök: nem feldolgozott termékek (primary), nyersanyagigényes termékek két csoportja (resource-based): mezőgazdasági és egyéb nyersanyagokon alapuló termékek, alacsony technológiájú termékek két csoportja: textiliák és egyebek, közepes technológiai termékek három csoportja (gépkocsik, feldolgozott termékek (process) és müszaki termékek (engineering), csúcstechnológiájú termékek két csoportja: elektronikus és elektromos termékek továbbá egyéb, valamint nem besorolt termékek (A. táblázat a mellékletben).

Vannak olyan tanulmányok, melyek szerzői egyes kiválasztott országok kereskedelmének áruszerkezetét a Lall osztályozás alkalmazásával elemzik (pl. Trindade és Pereira Oliveira (2017) - Brazilia; Sampath i Vallejo (2018) - 74 fejlődő ország csoportja; Bagaria és Ismail (2018) - India és Kina). Nem találtunk viszont ilyen tanulmányt Lengyelországra vonatkozóan. Csupán olyan tanulmányok léteznek, amelyek közvetve utalnak az áruk technológia igényességére (pl. Michalski (2014) vagy Cieślik, Michalek és Szczygielski (2016)), viszont nem kerül alkalmazásra bennük a Lall osztályozás. Ezért döntöttünk a lengyel export vizsgálatára ezen osztályozás alkalmazásával.

\section{Export Lengyelországból}

A lengyel kivitel nagyságának elemzésével kezdjük (az 1. táblázat első sora). A tanulmány által vizsgált időszaknak csak első és utolsó évéről kapott információk valamivel eltérő képet adnának, mint az összes év elemzése. Ha a figyelmet ezen határos évekre összpontosítanánk, csak a lengyel kivitel jelentős (több, mint háromszoros) növekedését látnánk. Az egyes évek elemzése feltárja az elemzés kezdete és vége között jelentkező ingadozásokat. Így látható, hogy az export értéke 2009-ben, 2012-ben és 2015-ben csökkent. A legmélyebb a 2009-ben bekövetkezett visszaesés, ám a többi csökkenéshez hasonlóan, azt gyorsan kompenzálták a további növekedések. Az export értékének 2009-es csökkenése egyértelműen összefüggett a kereskedelem világméretü összeomlásával, de már 2010 növekedést hozott, és egy évvel később az export volumene meghaladta az akkori rekordértéket 2008-ból. 
1. táblázat A lengyel kivitel értéke a 2004-2017-es időszakban partnerek szerint, folyó árakon és árfolyamokon, milliárd dollárban

\begin{tabular}{|c|c|c|c|c|c|c|c|c|c|c|c|c|c|c|}
\hline & 2004 & 2005 & 2006 & 2007 & 2008 & 2009 & 2010 & 2011 & 2012 & 2013 & 2014 & 2015 & 2016 & 2017 \\
\hline $\begin{array}{l}\text { Összes } \\
\text { export }\end{array}$ & 75 & 89 & 111 & 140 & 170 & 137 & 160 & 189 & 185 & 205 & 220 & 199 & 204 & 234 \\
\hline $\begin{array}{l}\text { Export } \\
\text { az } \\
\text { EU-ba }\end{array}$ & 60 & 71 & 87 & 110 & 134 & 109 & 124 & 147 & 136 & 152 & 164 & 153 & 155 & 175 \\
\hline $\begin{array}{l}\text { Export } \\
\text { az EU-n } \\
\text { kívül }\end{array}$ & 15 & 18 & 24 & 30 & 36 & 28 & 36 & 42 & 49 & 53 & 56 & 46 & 49 & 59 \\
\hline
\end{tabular}

Forrás: Az UNCTAD adatain alapuló saját tanulmány (UNCTAD 2019a).

A lengyel kivitel volumenének változásait az 1. ábra is szemlélteti, amelyen ezen túlmenően megmutatjuk a behozatal nagyságát és ezáltal a kereskedelmi mérleg egyenlegét is. Ez az egyenleg - a vizsgált időszak (2004 és 2014 közötti) domináns részében negatív - a legérdekesebb, mivel azt mutatja, hogy a lengyel kivitel - bár a 2009-es válságon kívül dinamikusan növekedett, nem tartott lépést az importtal, amely nagyrészt szükséges volt, és abból származott, hogy ki kellett elégítenie a növekvő gazdaság nyersanyagok, valamint modern befektetési és fogyasztási cikkek iránti igényeit. 2015-ben és 2016-ban az export meghaladta az importot, ezt követően 2017-ben a kereskedelem kiegyensúlyozott volt. Az utolsó három év ezért eltérőnek tekinthető az előző időszakhoz képest, mivel Lengyelország már nem mutatott fel kereskedelmi hiányt, és az exporttal (2015-ben és 2016-ban többlettel) fedezni tudta a beruházási és fogyasztási importot.

1. ábra Lengyelország exportjának és importjának értéke a 2004 és 2017 közötti időszakban, folyó árakon és árfolyamokon, milliárd dollárban

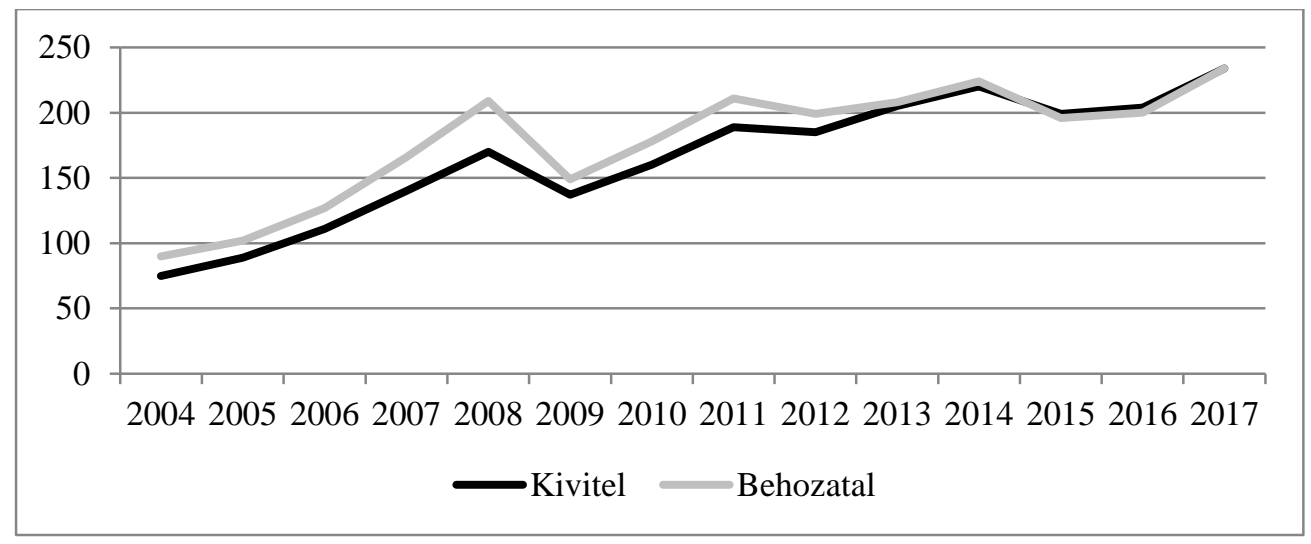

Forrás: saját tanulmány UNCTAD adatai alapján (UNCTAD 2019a).

A lengyel export éves ingadozása részletesen kimutatható éves százalékos változások segítségével (2. táblázat). Ezúttal is világosan látjuk a 2009-es kereskedelem összeomlásának hatásait, amikor a lengyel export 2008-hoz képest több 
mint 19\% -kal csökkent. A 3. táblázatban szereplő adatok elemzése azt is feltárja, hogy a lengyel kivitel a legerőteljesebben a világméretủ válság elött, 2007-ben, nőtt (2006-hoz képest 26,1\% -kal nött akkor). Általában véve a növekedés nagyobb volt az EU-hoz való csatlakozás utáni első években. Nem haladták meg ezt a szintet a 2010-es és 2011-es növekedések, amelyek jócskán ellensúlyozták a 2009-es visszaesést.

2. táblázat A lengyel kivitel értékének éves változásai 2004 és 2017 között, \%

\begin{tabular}{ccccccccccccc}
\hline $\mathbf{2 0 0 5 /}$ & $\mathbf{2 0 0 6 /}$ & $\mathbf{2 0 0 7 /}$ & $\mathbf{2 0 0 8 /}$ & $\mathbf{2 0 0 9 /}$ & $\mathbf{2 0 1 0 /}$ & $\mathbf{2 0 1 1 /}$ & $\mathbf{2 0 1 2 /}$ & $\mathbf{2 0 1 3 /}$ & $\mathbf{2 0 1 4 /}$ & $\mathbf{2 0 1 5 /}$ & $\mathbf{2 0 1 6 /}$ & $\mathbf{2 0 1 7 /}$ \\
$\mathbf{2 0 0 4}$ & $\mathbf{2 0 0 5}$ & $\mathbf{2 0 0 6}$ & $\mathbf{2 0 0 7}$ & $\mathbf{2 0 0 8}$ & $\mathbf{2 0 0 9}$ & $\mathbf{2 0 1 0}$ & $\mathbf{2 0 1 1}$ & $\mathbf{2 0 1 2}$ & $\mathbf{2 0 1 3}$ & $\mathbf{2 0 1 4}$ & $\mathbf{2 0 1 5}$ & $\mathbf{2 0 1 6}$ \\
\hline 18,7 & 24,7 & 26,1 & 21,4 & $-19,4$ & 16,8 & 18,1 & $-2,1$ & 10,8 & 7,3 & $-9,5$ & 2,5 & 14,7 \\
\hline
\end{tabular}

Forrás: saját tanulmány UNCTAD adatai alapján (UNCTAD 2019a) (21.06.2019).

A lengyel exportnak a figyelembe vett időszak elején való erőteljes növekedésének fö oka a korábbi időszak kereskedelmi forgalmának viszonylag alacsony volumene volt. Oka volt a lengyel export versenyképességének javulása is, amelyet a gazdaságnak a rendszer transzformációja alatt és után való modernizálása és szerkezetátalakítása eredményezett.

3. táblázat A lengyel kivitel részesedése a világ exportjában a 2004-2017 közötti időszakban, \%

\begin{tabular}{|c|c|c|c|c|c|c|c|c|c|c|c|c|c|c|}
\hline & 2004 & 2005 & 2006 & 2007 & 2008 & 2009 & 2010 & 2011 & 2012 & 2013 & 2014 & 2015 & 2016 & 2017 \\
\hline $\begin{array}{l}\text { Kivitel } \\
\text { Lengyel- } \\
\text { országból/ } \\
\text { Világkivitel }\end{array}$ & 0,8 & 0,9 & 0,9 & 1,0 & 1,1 & 1,1 & 1,0 & 1,0 & 1,0 & 1,1 & 1,2 & 1,2 & 1,3 & 1,3 \\
\hline
\end{tabular}

Forrás: saját tanulmány UNCTAD adatai alapján (UNCTAD 2019a) (21.06.2019).

A 2004-2017-es években növekedett a lengyel export, ami azonban nem tette Lengyelországot globális kereskedelmi hatalommá (3. táblázat). A lengyel export részesedése a globális külkereskedelemben 2004 és 2017 között növekedett, azonban Lengyelország továbbra is jelentéktelen résztvevője maradt a világ exportjának. A lengyel részesedés növekedésének döntő része a gazdasági válság elött történt. Érdekes, hogy a kereskedelem összeomlásának válságévében (2009) a lengyel export részesedése a globális exportban továbbra is a 2008-as év szintjén maradt, és csak később csökkent 0,1 százalékponttal, állandó szinten maradva 3 éven keresztül, hogy 2013-2017-ben ismét enyhén emelkedjen rekordszintre (1,3\%).

\section{Export Lengyelországból az Európai Unió-beli partnerek felé és harmadik országokba}

Az általános elemzés után megvizsgáljuk az EU-ba és a csoporton kívüli országokba irányuló lengyel export változásait (az 1. táblázat 2. sora és a 2. ábra). A 2. ábrán láthatjuk, hogy a 2008-as válságig az EU-ba és a többi országba irányuló a lengyel 
export hasonlóan változott. Ezt bizonyítja mindkét vonal viszonylag hasonló formája, amely szemlélteti a teljes exportot és az EU-ba irányuló kivitelt (a vonalak közötti távolság szemlélteti az Unión kívüli országokba irányuló növekvő lengyel kivitelt). 2009 után az EU-partnerek felé irányuló kivitel stabilabb lett és 2016-ig lassabban nőtt, mint a harmadik országokba irányuló kivitel. Tekintettel az EU domináns helyzetére a lengyel exportban, ez jó hír, mivel bizonyítja a lengyel áruk nemzetközi helyzetének javulását azokon a piacokon is, ahol akadályok korlátozzák a bejutást ${ }^{2}$. Ez többek között előnyös a lengyel áruk vevőinek diverzifikációja és az EUpartnerektől való függetlenség miatt. Összességében 2004-2017-ben az EU-országok részesedése a lengyel exportban 5,2 százalékponttal csökkent 80\% -ról 74,8\% -ra. E csökkenés ellenére az értékesítés dominációja az EU piacon továbbra is hatalmas marad. 2017-ben az exportnak köszönhetően minden zlotyból közel 75 grosz érkezett az Európai Unió országaiból. 2004-ben ez még több volt, mivel 80 grosz.

2. ábra A lengyel export értéke folyó árakon és árfolyamokon, milliárd dollárban

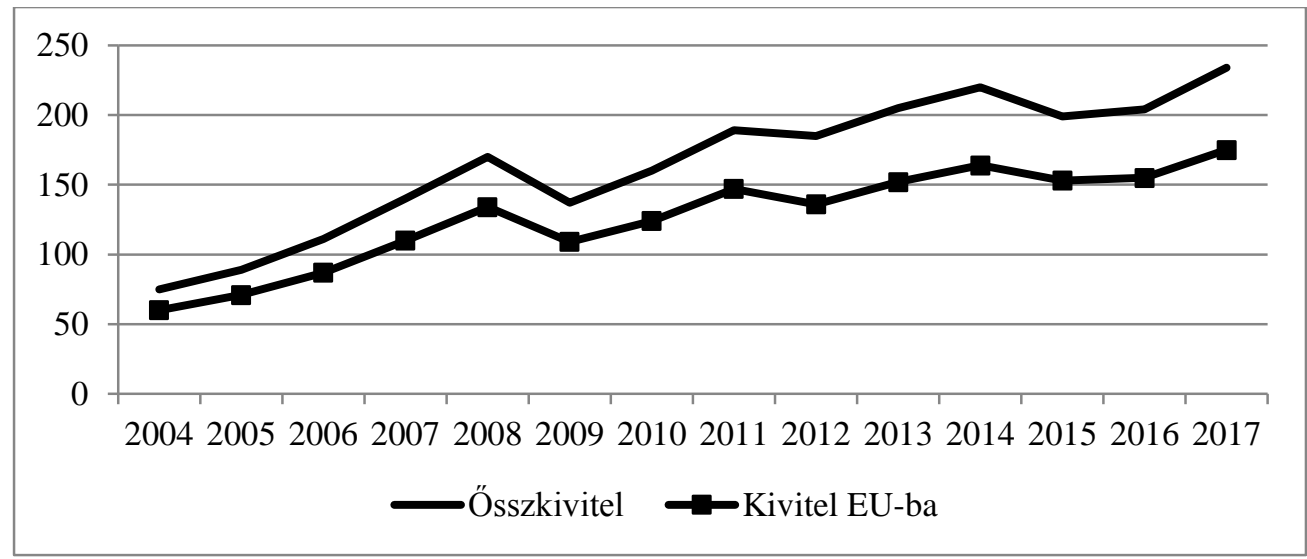

Forrás: saját tanulmány UNCTAD adatai alapján (UNCTAD 2019a).

4. táblázat Az Európai Unióba irányuló lengyel kivitel aránya a teljes lengyel kivitelben, \%

\begin{tabular}{lcccccccccccccc}
\hline & $\mathbf{2 0 0 4}$ & $\mathbf{2 0 0 5}$ & $\mathbf{2 0 0 6}$ & $\mathbf{2 0 0 7}$ & $\mathbf{2 0 0 8}$ & $\mathbf{2 0 0 9}$ & $\mathbf{2 0 1 0}$ & $\mathbf{2 0 1 1}$ & $\mathbf{2 0 1 2}$ & $\mathbf{2 0 1 3}$ & $\mathbf{2 0 1 4}$ & $\mathbf{2 0 1 5}$ & $\mathbf{2 0 1 6}$ & $\mathbf{2 0 1 7}$ \\
\hline $\begin{array}{l}\text { Export az } \\
\begin{array}{l}\text { EU-ba/ } \\
\text { Összes } \\
\text { export }\end{array}\end{array}$ & 80,0 & 79,8 & 78,4 & 78,6 & 78,8 & 79,6 & 77,5 & 77,8 & 73,5 & 74,1 & 74,5 & 76,9 & 76,0 & 74,8 \\
\hline
\end{tabular}

Forrás: saját tanulmány UNCTAD adatai alapján (UNCTAD 2019a).

\footnotetext{
2 Érdemes emlékezni arra, hogy a XXI. században az EU fontos megállapodásokat kötött a gazdasági együttmüködés diszkriminatív liberalizációjáról (a WTO értelmében - Regional Trade Agreement, RTAk). Ennek eredményeként sok nem uniós, különösen ázsiai, piacra való hozzáférés is szabadabbá vált, ami növelte a lengyel exportlehetöségeket.
} 
Az árucseremérleg egyenlege is érdekes mindkét partnercsoport esetében (UNCTAD 2019a). 2004 után Lengyelországban állandó többlet mutatkozik az EUval folytatott kereskedelemben, míg a tanulmány által vizsgált teljes időszakban hiány mutatkozik a kereskedelemben az EU-n kívüli országokkal. Így Lengyelország 2014ig folyamatosan mutatkozó teljes kereskedelmi hiánya az EU-n kívüli országokkal való negatív kereskedelmi mérleg eredménye. Ez azt jelenti, hogy Lengyelország állandóan és erősen függ az EU-n kívüli beszerzésektől. Különösen a nyersanyagok beszerzésére vonatkozik ez, beleértve az energiaforrásokat. Ugyanakkor, még jóval az EU-ba való csatlakozás után sem tudta biztosítani termékei olyan szintü értékesítését, amely finanszírozhatná a szükséges behozatalt. A hiány fedezése csak az EU-n belüli kereskedelem növekvő többletének köszönhetően vált lehetővé. 2012 óta a kereskedelem teljes hiánya csökkent és 2015-ben kisméretü többlet váltotta fel, amely azonban 2017-ben nullára olvadt. Igy, több évi mélyülő hiány után - az EU-n belüli kereskedelem többletének köszönhetően - Lengyelország kereskedelmi mérlegének egyenlege többletet mutatott. Ez tekinthető annak a legrövidebb leírásának, hogy milyen nagy jelentősége van az Európai Unióban való tagságnak a külföldi országokkal folytatott lengyel kereskedelemben.

\section{A lengyel áruk fó átvevői}

A lengyel kivitel fó vásárlóinak elhelyezkedése mutatja a kivitel földrajzi irányait is. Mivel a kereskedelmi partnerek változása lassabban történik, mint az export volumenének változása (pl. hosszútávú szerződések és jól megalapozott kereskedelmi kapcsolatok miatt), ezt az elemzést a vizsgált időszak elejére és végére korlátozzuk (5. táblázat).

A lengyel áruk vásárlói listájának az élén 2004-ben Németország állt, és 2017-ben is ott maradt, s mely ország 38 milliárd USD-vel növelte a lengyelországi vásárlásokat az elemzett időszakban (Németország szintén a vezető szerepét töltötte be a lengyel importban - lásd (UNCTAD 2019a). A lengyel export átvevőinek rangsorában a további helyeken változott a sorrend, bár az első öt hely összetétele változatlan maradt. Míg 2004-ben Lengyelország (Németországon kivül) elsősorban Olaszországba és Franciaországba szállított árut (10 milliárd USD értékü árut vásárolva Lengyelországban, ami a német vásárlások értékének körülbelül 45,5\% -át tette ki), addig 2017-ben a helyüket Nagy-Britannia és Csehország foglalta el (az oda irányuló lengyel kivitel teljes értéke 28 milliárd USD volt, azaz a Németországba irányuló kivitel 46,7\% -a). További helyeket foglalt el 2004-ben Nagy-Britannia és a Csehország, míg 2017-ben Franciaország és Olaszország. Így ebben a besorolásban is az EU-beli partnerek dominálnak. 
5. táblázat A lengyel kivitel fő átvevői (értékek folyó árakon és árfolyamokon, milliárd dollárban)

\begin{tabular}{ll}
\hline \multicolumn{1}{c}{$\mathbf{2 0 0 4}$} & \multicolumn{1}{c}{$\mathbf{2 0 1 7}$} \\
\hline Németország: 22 & Németország: 60 \\
Olaszország: 5 & Nagy-Britannia: 14 \\
Franciaország: 5 & Cseh Köztársaság: 14 \\
Nagy-Britannia: 4 & Franciaország: 12 \\
Cseh Köztársaság: 3 & Olaszország: 11 \\
\hline
\end{tabular}

Forrás: saját tanulmány UNCTAD adatai alapján (UNCTAD 2019a).

A lengyel áruk legfontosabb átvevőire vonatkozó adatok elemzése nem deríti ki a Lengyelországgal folytatott kereskedelemben való részvételük okait. Németország domináns helyének magyarázata a Lengyelországgal folytatott kereskedelemben a következők: a partnerek földrajzi közelsége, a német gazdaság nagysága, technológiai fejlettsége és a német társadalom gazdagsága. A nagy és viszonylag gazdag EU-országokhoz tartozó Franciaország és Olaszország szintén a lengyel áruk természetes átvevői. A helyük romlását 2017-ben Nagy-Britannia miatt elsősorban a Lengyelországból származó emigránsok Nagy-Britanniába való beáramlása okozza, akik nemcsak, hogy lengyel termékeket vásárolnak, hanem terjesztik is a rájuk vonatkozó ismereteket a helyi társadalomban. A lengyel kivitel helyzetének javulása Nagy-Britanniában, a viszonylag nagy földrajzi távolság és a korábbi kolóniákkal fenntartott hagyományos brit gazdasági kapcsolatok ellenére, megmutatja az emigráció kereskedelemre gyakorolt hatásának erejét. Nagy-Britannia növekvő jelentősége a lengyel kivitel szempontjából szintén bizonyítja a Brexit problémájának súlyát. Csehország előrelépése viszont a lengyel áruk átvevőinek körében igazolja a visszatérést a Lengyelország és ezen ország (korábban Csehszlovákia) közötti hagyományos kereskedelmi kapcsolatokhoz.

\section{A lengyel kivitel áruszerkezeti felépítése a termékek technológia igényességének figyelembe vételével}

Ebben a részben megvizsgáljuk a lengyel kivitel áruszerkezetét a termékek technológia igényességének figyelembe vételével A Lall osztályozást azért használjuk, mert meg akarjuk vizsgálni, hogy Lengyelország az EU-csatlakozás óta eltelt több mint 13 év alatt, milyen mértékben modernizálta gazdasága áruszerkezetét, és tette hasonlóvá a magasan fejlett országok (azaz például az EU-15 országai) tudáson és innováción alapuló gazdaságaihoz. 
6. táblázat A lengyel árukivitel szerkezete a Lall (2000) osztályozás szerint a 2004-2017 közötti időszakban, \%

\begin{tabular}{|c|c|c|c|c|c|c|c|c|c|c|c|c|c|c|}
\hline & 2004 & 2005 & 2006 & 2007 & 2008 & 2009 & 2010 & 2011 & 2012 & 2013 & 2014 & 2015 & 2016 & 2017 \\
\hline Alaptermékek & 9 & 10 & 10 & 9 & 8 & 9 & 10 & 10 & 11 & 11 & 10 & 10 & 9 & 9 \\
\hline $\begin{array}{l}\text { Nyersanyagokon alapuló nyersanyagigényes } \\
\text { termékek }\end{array}$ & 11 & 11 & 11 & 11 & 10 & 11 & 12 & 12 & 12 & 13 & 13 & 12 & 13 & 13 \\
\hline $\begin{array}{l}\text { Nem mezőgazdasági nyersanyagokon alapuló } \\
\text { nyersanyagigényes termékek }\end{array}$ & 7 & 6 & 7 & 6 & 7 & 5 & 7 & 7 & 7 & 7 & 7 & 6 & 5 & 5 \\
\hline Alacsony technológiájú termékek: textiliák & 6 & 5 & 4 & 4 & 4 & 4 & 4 & 4 & 4 & 4 & 4 & 4 & 5 & 5 \\
\hline Alacsony technológiájú termékek: egyéb & 19 & 18 & 17 & 18 & 17 & 16 & 16 & 16 & 16 & 16 & 16 & 17 & 17 & 18 \\
\hline Közepes technológiai termékek: gépkocsik & 12 & 12 & 13 & 13 & 14 & 14 & 13 & 12 & 11 & 10 & 10 & 10 & 12 & 11 \\
\hline Közepes technológiai termékek: feldolgozott áruk & 7 & 7 & 7 & 7 & 8 & 7 & 8 & 8 & 8 & 8 & 8 & 8 & 8 & 8 \\
\hline Közepes technológiai termékek: műszaki termékek & 21 & 20 & 20 & 20 & 18 & 17 & 17 & 17 & 17 & 18 & 18 & 19 & 18 & 17 \\
\hline $\begin{array}{l}\text { Csúcstechnológiai termékek: elektronikus és } \\
\text { elektromos termékek }\end{array}$ & 6 & 6 & 7 & 8 & 10 & 12 & 12 & 10 & 10 & 9 & 10 & 10 & 9 & 9 \\
\hline Csúcstechnológiai termékek: egyéb & 1 & 1 & 1 & 1 & 2 & 2 & 2 & 2 & 2 & 3 & 3 & 3 & 3 & 3 \\
\hline
\end{tabular}

Forrás: Az UNCTAD adatain alapuló saját tanulmány (UNCTAD 2019b). 
A 6. táblázatban szereplő adatok azt mutatják, hogy a 2004-2017-es években nem történt forradalom a lengyel kivitel áruszerkezetében, bár nehéz nem észrevenni, hogy enyhe javulást tapasztalunk. A tizenegy termékcsoportból három részaránya nem változott: alaptermékek, gépkocsik és besorolás nélküli termékek. Négy csoport részesedése csökkent: a nem mezőgazdasági nyersanyagokon alapuló nyersanyagigényes termékek, textiliák és egyéb alacsony technológiai termékek és müszaki termékek. A fennmaradó négy csoport részesedése nőtt, nevezetesen: mezőgazdasági nyersanyagokon alapuló termékek, feldolgozott áruk, valamint mindkét csúcstechnológiai termékcsoport (elektronikus, elektromos és egyéb).

A lengyel kivitel áruszerkezetében bekövetkező változások irányai kedvezőek a gazdaság számára, ám a változások nagyon lassan zajlanak. Lengyelország eltávolódik a nyersanyag- és munkaigényes specializálódásától (kivétel a mezőgazdasági nyersanyagokon alapuló termelés, ez azonban megerősíti a lengyel mezőgazdaság, valamint az élelmiszer- és faiparipar jó állapotát, tehát pozitív tünet). A csúcstechnológiájú termékek veszik át a nyers- és munkaigényes termékek helyét, bár ezek arányát az exportban (2017-ben 12\%, szemben a 2004-es 7\% -kal) még mindig nehéz kielégítőnek tekinteni. Az is aggasztó, hogy 2009 után nem történt áttöréses változás. Jóllehet, egyéb csúcstechnológiai termékek részesedése 1 százalékponttal növekedett, de ugyanakkor 3 százalékponttal csökkent az elektronikai és elektromos termékek részesedése, igy a csúcstechnológiájú termékek teljes részesedése 2 százalékponttal esett. A közepes technológiai termékek teljes részesedése nem változott (2009-ben és 2017-ben is 38\%-ot tett ki). 2 százalékponttal nőtt az alacsony technológiai termékek aránya a lengyel exportban.

\section{7. Összefoglalás}

Lengyelország tagsága az Európai Unióban hozzájárult exportjának növekedéséhez mind az Európai Unióba, mind az EU-n kívüli országokba. Az EU normáinak és szabványainak alkalmazása, a külföldi befektetések beáramlása és a nemzetközi piacok ismerete hozzájárult a lengyel áruk nemzetközi versenyképességének javulásához. Következésképpen, az elmúlt években a nagy kereskedelmi hiányt kis többlet váltotta fel. Lengyelország azonban ezt a többletet csak az EU-partnerekkel folytatott kereskedelemben generálja, mivel folyamatosan hiányokat mutat a harmadik országokkal folytatott kereskedelemben. Ennélfogva nem képes lemondani a szükséges behozatalról, nem tudva biztosítani áruinak értékesitését olyan piacokon, ahol nem rendelkezik olyan szabad hozzáféréssel, mint az EU-ban.

A lengyel kivitel áruszerkezete javul, és közepes és csúcstechnológiájú termékek irányába fejlődik. Ez a folyamat azonban nagyon lassú, ami rosszabb, 2009 után ráadásul le is fékeződött. Igy a lengyel export technológia igényessége a 20042017 években nem tekinthető jelentősnek. Ez azt jelenti, hogy Lengyelország nem érte el a magasan fejlett országok szintjét (mint például Németország - lásd CzarnyZmuda 2018) és nem vált olyan gazdasággá, amely tudáson i innováción alapul. Lassan, bár eléggé szisztematikusan, egyre nő a mezőgazdasági nyersanyagokon alapuló lengyel exporttermékek jelentősége. 


\section{Felhasznált irodalom}

Bagaria, N. - Ismail, S. (2018): Technological Intensity of India and China: A Comparative Assessment. Journal of International Economics, 8, 2, 50-59.

Cieślik, A. - Michałek, J. J. - Szczygielski, K. (2016): Innovations and Export Performance: Firm-level Evidence from Poland. Entrepreneurial Business and Economics Reviews, 4, 4, 11-28.

Czarny, E. - Śledziewska, K. (2012): Międzynarodowa wspótpraca gospodarcza w warunkach kryzysu. Wnioski dla Polski. PWE, Warszawa.

Czarny, E. - Żmuda, M. (2018): Competitiveness as the Ability to Adjust: The EU10 Exports Structure and Its Convergence to the German Pattern. Comparative Economic Research, 21, 1, 119-132.

Lall, S. (2000): The Technological Structure and Performance of Developing Country Manufactured Exports, 1985-1998. QEH Working Paper Series, No. 44. https://pdfs.semanticscholar.org/25c1/ecbbc9c968a56451bf54760af6b80a811 004.pdf

Michalski, B. (2014): Competitiveness of Polish Mid-tech and High-tech Exports to the European Union in the First Decade of $21^{\text {st }}$ Century. Poznań University of Economics Review, 14, 4, 54-70.

Sampath, P. G. - Vallejo, B. (2018): Trade, Global Value Chains and Upgrading: What, When and How? The European Journal of Development Research, 30, 3, 481-504.

Trindade, J. R. - Pereira de Oliveira, W. (2017): Padrao de Especializacao PrimarioExportador e Dinamica de Dependencia no Period 1990-2010, no Economia Brasileira. Ensaios FEE, 37, 4, 1059-1092.

UNCTAD (2019a): International trade in goods and services. https://unctadstat.unctad.org/wds/ReportFolders/reportFolders.aspx?sCS Cho senLang=en (belépés: 21.06.2019).

UNCTAD (2019b): Merchandise trade matrix - product groups, exports in thousands of United States dollars, annual.

https://unctadstat.unctad.org/wds/TableViewer/tableView.aspx?ReportId=24739 (belépés: 21.06.2019). 


\section{Melléklet}

A. táblázat: Az export áruszerkezete Lall szerint

\begin{tabular}{|c|c|}
\hline Besorolás & Áruk példái \\
\hline PRIMARY PRODUCTS & $\begin{array}{l}\text { fresh fruit, meat, rice, cocoa, tea, coffee, } \\
\text { wood, coal, crude petroleum, gas }\end{array}$ \\
\hline \multicolumn{2}{|l|}{ MANUFACTURED PRODUCTS } \\
\hline \multicolumn{2}{|l|}{ Resource based manufactures } \\
\hline Agro/forest based products & $\begin{array}{l}\text { prepared meats/fruits, beverages, wood } \\
\text { products, vegetable oils }\end{array}$ \\
\hline Other resource based products & $\begin{array}{l}\text { ore concentrates, petroleum/rubber products, } \\
\text { cement, cut gems, glass }\end{array}$ \\
\hline \multicolumn{2}{|l|}{ Low technology manufactures } \\
\hline Textile/fashion cluster & $\begin{array}{l}\text { textile fabrics, clothing, headgear, footwear, } \\
\text { leather manufactures, travel goods }\end{array}$ \\
\hline Other low technology & $\begin{array}{l}\text { pottery, simple metal parts/structures, } \\
\text { furniture, jewellery, toys, plastic products }\end{array}$ \\
\hline \multicolumn{2}{|l|}{ Medium technology manufactures } \\
\hline Automotive products & $\begin{array}{l}\text { passenger vehicles and parts, commercial } \\
\text { vehicles, motorcycles and parts }\end{array}$ \\
\hline $\begin{array}{l}\text { Medium technology process } \\
\text { industries }\end{array}$ & $\begin{array}{l}\text { synthetic fibres, chemicals and paints, } \\
\text { fertilisers, plastics, iron, pipes/tubes }\end{array}$ \\
\hline $\begin{array}{l}\text { Medium technology engineering } \\
\text { Industries }\end{array}$ & $\begin{array}{l}\text { engines, motors, industrial machinery, } \\
\text { pumps, switchgear, ships, watches }\end{array}$ \\
\hline \multicolumn{2}{|l|}{ High technology manufactures } \\
\hline Electronics and electrical products & $\begin{array}{l}\text { office/data processing/telecommunications } \\
\text { equip, TVs, transistors, turbines, power } \\
\text { generating equipment }\end{array}$ \\
\hline Other high technology & $\begin{array}{l}\text { pharmaceuticals, aerospace, } \\
\text { optical/measuring instruments, cameras }\end{array}$ \\
\hline OTHER TRANSACTIONS & $\begin{array}{l}\text { electricity, cinema film, printed matter, } \\
\text { 'special' transactions, gold, art, coins, pets }\end{array}$ \\
\hline
\end{tabular}

Forrás: saját tanulmány Lall S. alapján: (Lall 2000, 7. o.). 